\title{
Metallic Contamination of the Muscles of Three Fish Species from the Moulouya River (Lower Moulouya, Eastern Morocco)
}

\author{
Mohammed Mahjoub (D), ${ }^{1}$ Mohammed El Maadoudi, ${ }^{2}$ and Youssef Smiri ${ }^{1}$ \\ ${ }^{1}$ Mohamed First University, Faculty of Sciences, Department of Biology, Laboratory of the Agricultural Production Improvement, \\ Biotechnology, and Environment, P.B. 717, Oujda, Morocco \\ ${ }^{2}$ National Office of Food Safety (ONSSA), Regional Laboratory of Analysis and Research, P.B. 3, Tangier, Morocco \\ Correspondence should be addressed to Mohammed Mahjoub; mahjoub.med90@gmail.com
}

Received 10 April 2020; Revised 16 August 2020; Accepted 9 September 2020; Published 21 September 2020

Academic Editor: Agoes Soegianto

Copyright (C) 2020 Mohammed Mahjoub et al. This is an open access article distributed under the Creative Commons Attribution License, which permits unrestricted use, distribution, and reproduction in any medium, provided the original work is properly cited.

\begin{abstract}
This study introduces a spatiotemporal evaluation of the metallic contamination with three trace metals (mercury, lead, and cadmium) in the muscles of three fish species (Lepomis macrochirus, Barbus callensis, and Barbus nasus), of which the samples were taken from three stations in the Moulouya River: the confluence of the Moulouya River and the Sebra River (station 1), the neighbourhood of the farms in the region of Aklim downstream from confluence of Lakhmis river (station 2), and the level of ancient bridge of Ras El Ma-Moulouya (station 3), during the period from July 2017 to May 2018. The results have allowed us to highlight rather high contents of lead and mercury in the fish muscles, mainly in station 1, which receives domestic and industrial discharges. The contents of cadmium in all fish species in different stations are very low. Moreover, all concentrations assessed in different fish species do not exceed the maximum limit recommended by European Community (EC) Commission Regulation No. $1881 / 2006$.
\end{abstract}

\section{Introduction}

The Moulouya River, which extends over a $520 \mathrm{~km}$ length, is considered to be the blue artery of the eastern region of Morocco. It has a major socioeconomic importance; it is used for irrigation. It is also a source of drinking water and has a big wealth of flora and fauna aquatic [1]. Fishery resources are among the most present animals in the river. The study of Melhaoui and Boudo in 2009 [2] revealed the presence of 29 species. The 29 species are distributed in the upper, middle, and lower regions of Moulouya. The abundance of fishery resources is more in the lower part, with an important activity of fishing along the river. On the contrary, at the higher and medium level, fish is not much varying, is very disseminated, and has weak density. This shows us that the fishing is mainly focused at the level of lower Moulouya.

The local industrial (oil mills, the Sucrafor sugar factory in Zaio), agricultural (the plain of Triffa and of Sebra), and urban activities (the cities: Taourirt, Zaio, Aklim, Berkane) can affect the quality of waters in this river by the discharge of many contaminants [3-5], making them inappropriate to use. This contamination will be able to impact negatively on biodiversity of fauna and flora of this river, which leads to intoxication and mortality of fauna, as in the case of July 15th, 2011, when thousands of fish were found dead and floating at the level of lower Moulouya [6].

Among the possible contaminants that can constitute a danger to aquatic life in general and the fish fauna especially are trace metals. They are very toxic even in weak concentrations and are characterized by their resistance to deterioration by organisms (not biodegradable), which causes their accumulation in the living organisms (the bioaccumulation) $[7,8]$. Therefore, the consumption of fishes contaminated with greater levels of trace metals can pose risks to health of humans. Among the wide range of trace metals contaminating the aquatic ecosystem, a major concern has been focused on cadmium, lead, and mercury. 
They are nonessential elements occupying top positions in all lists of toxicants $[9,10]$.

To the best of our knowledge, there is only one single study on the contamination of the fish of the Moulouya River by trace metals [11]; this study is limited to single species (Anguilla anguilla) at the level of single site, that is, the mouth of the Moulouya.

From this official report, we have gotten the idea of doing this study again, but on different types of fish species of the Moulouya River and in different stations. We led a new study on three different fish species and in a larger zone. This study introduces three main objectives: the first is to use the fish as indicator of the metallic pollution of Moulouya River, the second is to assess the largeness of the consumers' health risks, and the last is to know which fish species are most contaminated with trace metals.

This study is interested in lower Moulouya, from the confluence of the Moulouya and the Sebra River up to the mouth of Moulouya. This part of the river is chosen because it is the richest in fish in comparison with other zones, and it is known for fishing activities. This study also introduces a spatiotemporal evaluation of the metallic pollution of the fish fauna of lower Moulouya, by determining the most alarming and dangerous concentrations of trace metals (cadmium, lead, and mercury (for the first time)) in the muscles of three fish species.

\section{Materials and Methods}

2.1. Study Area and Sampling Stations. According to the different sources of water contaminations of the Moulouya River in the zone of lower Moulouya (domestic, industrial, agricultural contamination), the fish samples in this zone were collected from three stations (Figure 1):

(i) Station $3\left(35^{\circ} 03^{\prime} 05.1^{\prime \prime} \mathrm{N} 2^{\circ} 25^{\prime} 43.1^{\prime \prime} \mathrm{W}\right)$ : It is at the level of the ancient bridge of Ras El Ma-Moulouya, which is located downstream from confluence of the Charaâ River and Moulouya River (Figure 2). It is chosen to estimate the impact of the contributions of the Charaâ River, which drains wastewaters of the city of Berkane on the fish of Moulouya River.

(ii) Station $2\left(34^{\circ} 57^{\prime} 01.2^{\prime \prime} \mathrm{N} \mathrm{2} 2^{\circ} 29^{\prime} 49.4^{\prime \prime} \mathrm{W}\right)$ : This zone is at the level of the area of the farms of Aklim region and downstream from confluence of the Lakhmis River and Moulouya River. It is characterized by a good extension of agricultural fields (Figure 2). It was chosen for search due to the possible pollution of fish caused by agricultural activities and for the purpose of assessing the impact of the contributions of the Lakhmis River, which drains wastewaters of the city of Aklim on the fish of Moulouya River.

(iii) Station $1\left(34^{\circ} 53^{\prime} 11.2^{\prime \prime} \mathrm{N} 2^{\circ} 39^{\prime} 38.9^{\prime \prime} \mathrm{W}\right)$ : It is located at the level of confluence of the Moulouya River and the Sebra River; the latter drains the effluents from the sugar factory (Sucrafor, Zaio) and domestic wastewater from the city of Zaio and mixes them with the waters of the Moulouya River (Figure 2).

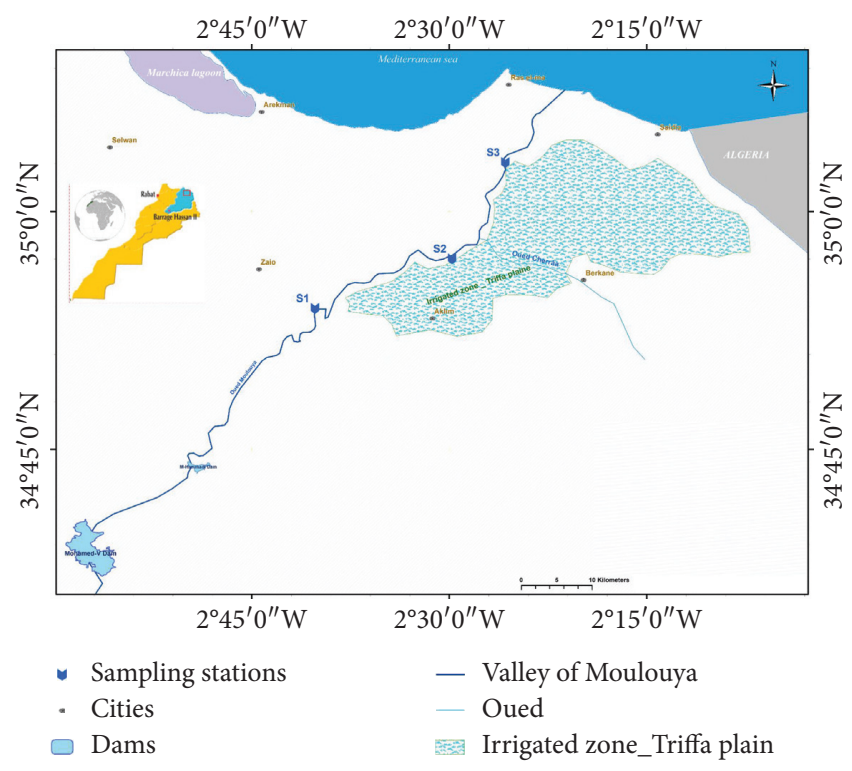

FIgURE 1: Localization map of the study area and location of sampling stations area.

Therefore, it is chosen to evaluate the impact of inflows of Sebra River on fish of Moulouya River.

2.2. Sampling. Seasonal sampling missions were spread over the four seasons from summer of 2017 until spring of 2018. The fish samples were captured using a combination of fishing rods and gill nets of various mesh sizes; we determined the species to which every fish belonged using keys by Azeroual (2003) [12]. A total of 121 individuals representing 3 species (Lepomis macrochirus, Barbus callensis, and Barbus nasus) were collected. The standard length $(\mathrm{cm})$ and weight ( $\mathrm{g}$ ) of each fish were determined using a vernier caliper and an analytical pocket balance, respectively. The individuals belonging to the same species were conditioned in the same polyethylene bags, which contained a chip of identification assuring their marking, then stocked in a cool box where the temperature is about $4^{\circ} \mathrm{C}$; after that, they were routed in the laboratory, where they were frozen at $-25^{\circ} \mathrm{C}$ until the instant of the analysis.

2.3. Metal Analysis. The fish samples were taken to the Regional Laboratory of Analysis and Research of National Office of Food Safety (RLAR, ONSSA) in Tangier, where they were dissected using stainless steel scalpels. We were interested in the edible parts of the fish that were ground and homogenized by a domestic food blender. At least three fish individuals were used as samples for trace metal analysis at each station, and each sample was analyzed three times to get the average value of metal content in fish. Mineralization was performed according to the technique described by AOAC Official Method [13], where a quantity varying between $0.5 \mathrm{~g}$ and $0.6 \mathrm{~g}$ of the homogenate mixture was treated, in a closed Teflon vessel, with $5 \mathrm{ml}$ of Suprapur (69\%) nitric acid $\left(\mathrm{HNO}_{3}\right)$ for mercury, and $5 \mathrm{ml}$ of Suprapur (69\%) $\mathrm{HNO}_{3}$ and $2 \mathrm{ml}$ of Suprapur (30\%) hydrogen peroxide (H2O2) for 


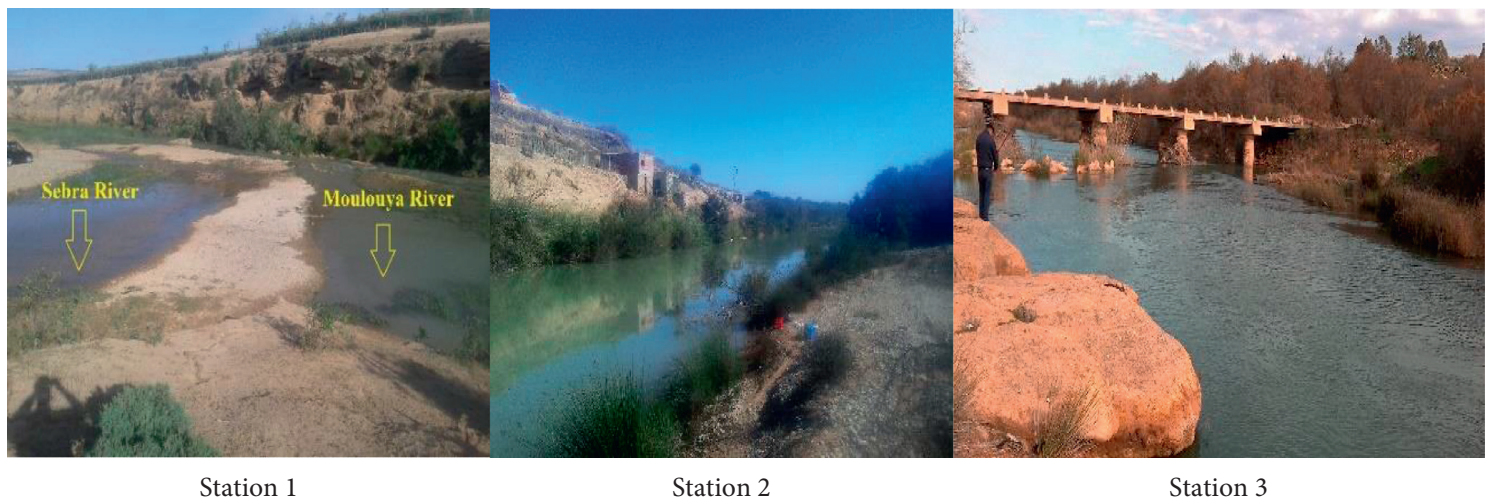

Figure 2: Pictures of different sampling stations.

lead and cadmium. The digestion flasks were then put on a microwave oven (Berghof speedwave MWS-2) and gradually heated (for 45 min up to $185 \mathrm{C}^{\circ}$ ) until all the materials were dissolved. After digestion and cooling to room temperature, the samples were diluted by $50 \mathrm{ml}$ with ultrapure water in polyethylene tubes.

The contents of trace metals were determined for lead and cadmium by a Graphite Furnace Atomic Absorption Spectrometry (GF-AAS) facility (Varian Perkin Elmer, ACE $800)$, equipped with a fully automated autosampler system. $2.5 \% \mathrm{NH}_{4} \mathrm{H}_{2} \mathrm{PO}_{4}$ and $1 \% \mathrm{Mg}\left(\mathrm{NO}_{3}\right)_{2}$ were the applied matrix modifiers. Mercury was quantified by Cold Vapour Atomic Absorption Spectrometry (CV-AAS) (VARIAN FIMS 100). The reducing agent used is stannous chloride $\left(\mathrm{SnCl}_{2}\right)$ at $2.5 \%$, and the carrier solution is hydrochloric acid $(\mathrm{HCl})$ at $3 \%$. For the two spectrometry techniques, using high purity argon as the carrier gas, the flow rate was $50 \mathrm{ml} / \mathrm{min}$.

2.4. Quality Assurance and Quality Control. All the tools used have been cleaned by soaking overnight in $\mathrm{HNO}_{3}$ $(10 \%)$, rinsed with ultrapure water, and dried before each use. In addition to $\mathrm{HNO}_{3}$, the Teflon vessels have been cleaned with acetone. All of the reagents employed in this study are of analytical grade. The calibration curve demonstrates good linearity for the three trace metals, with correlation coefficients $(r)$ greater than 0.999 (Table 1). The limit of quantification (LQ), the wavelength, and the standard calibration concentration of the present study are presented in Table 1.

According to ISO 17025, the accreditation laboratories that perform analytical service must have quality control procedure for monitoring the validity of tests undertaken [14]. The methods of GF-AAS and CV-AAS were accredited in laboratory (RLAR, ONSSA), and the accuracy of the analytical methods was evaluated by participation to proficiency test schemes. The test materials distributed were canned fish at different concentrations of cadmium, lead, and mercury, obtained from the Food Analysis Performance Assessment Scheme (FAPAS). Replicate analysis of these proficiency tests showed good accuracy, with recovery rates for trace metals between $97.67 \%$ and $100.46 \%$ (Table 2).

\section{Results and Discussion}

The number of fish individuals caught for each station and the biometric parameters (weight and length) of the fish species are summarized in Table 3.

The results of the spatiotemporal measure of metallic contents in the muscles of the different captured fish species are presented in Table 4 and Figure 3.

At all the stations, the results of cadmium concentration in the analyzed fish species are low. They vary from $0.001 \mathrm{mg} / \mathrm{kg}$ of wet weight in Barbus callensis and Lepomis macrochirus of station 2 to $0.006 \mathrm{mg} / \mathrm{kg}$ of wet weight in Barbus callensis captured in station 1 (Table 4).

Similar results were found in the muscles of Barbus meridionalis of the Ripoll River in Catalonia [15], of Luciobarbus graellsii, Rutilus rutilus, and Lepomis gibbosus in station 1 from the Llobregat River to Spain [16], and in Lepomis gibbosus from the Šalek Lakes in Slovenia [17]. A weak concentration of cadmium was revealed in the muscles of Barbus callensis and Liza ramada by El Morhit et al. [18] and in the muscles of Barbus barbus and Anguilla anguilla by Boscher et al. [19]. On the contrary, high concentrations of cadmium were obtained by Rajotte and Couture [20], Yi and Zhang [21], and Arantes et al. [22] (Table 5).

No significant correlation $(P<0.05)$ was found between cadmium and other trace metals in different species of fish in all stations (Table 6).

The order of the bioaccumulation of cadmium in the muscles of the studied fish is slightly high in Barbus nasus (Table 7).

Note that the concentration of cadmium in the muscles of studied fish species is much less than the regulation limit of cadmium in the flesh of fish $(0.05 \mathrm{mg} / \mathrm{kg}$ of wet weight) according to Commission Regulation (EC) No. 1881/2006 [28] (the same standard is adopted by Morocco).

The concentration of lead (Table 4) revealed in the muscles of the fish studied varies from $0.016 \mathrm{mg} / \mathrm{kg}$ of wet weight in Barbus callensis gotten in station 2 to $0.200 \mathrm{mg} / \mathrm{kg}$ of wet weight in Lepomis macrochirus of station 3. Similar levels were found by El Bouhali et al. [26], Merciai et al. [16], El Morhit et al. [18], and Djedjibegovic et al. [23]. However, low concentrations of lead were found by Maceda-Veiga et al. [15], Boscher et al. [19], Wariaghli et al. [27], and 
TABLE 1: The wavelength, limit of quantification (LQ), standard calibration concentration, and correlation coefficient $(r)$ for trace metals determination.

\begin{tabular}{lcccc}
\hline Trace metals & Wavelength $(\mathrm{nm})$ & LQ $(\mu \mathrm{g} / \mathrm{kg})$ & Standard calibration concentration $(\mu \mathrm{g} / \mathrm{L})$ & Correlation coefficient $(r)$ \\
\hline $\mathrm{Cd}$ & 228.8 & 0.01 & $0,0.1,0.2,0.4,0.8,1.6,3.2$ & 0.999830 \\
$\mathrm{~Pb}$ & 283.3 & 2.5 & $0,1,2,4,8,16,32$ & 0.999791 \\
$\mathrm{Hg}$ & 253.7 & 0.4 & $0,1,2.5,5,10,20$ & 0.999902 \\
\hline
\end{tabular}

TABLE 2: Trace metals determination in proficiency tests (FAPAS canned fish samples).

\begin{tabular}{lccc}
\hline Trace metals & Reference value $(\mathrm{mg} / \mathrm{kg}) \pm \mathrm{SD}$ & Observed value $(\mathrm{mg} / \mathrm{kg}) \pm \mathrm{SD}$ & Recovery $(\%)$ \\
\hline $\mathrm{Cd}$ & $6.2100 \pm 1.5100$ & $6.0655 \pm 0.2636$ & 97.67 \\
$\mathrm{~Pb}$ & $0.0526 \pm 0.0232$ & $0.0515 \pm 0.0083$ & 97.91 \\
$\mathrm{Hg}$ & $0.1080 \pm 0.0455$ & $0.1085 \pm 0.0129$ & 100.46 \\
\hline
\end{tabular}

SD: standard deviation.

TABLE 3: Number of fish individuals, weight, and length by sampling sites.

\begin{tabular}{lccc}
\hline Fish species & Number of fish & Mean weight $(\mathrm{g}) \pm \mathrm{SD}$ & Mean length $(\mathrm{cm}) \pm$ SD \\
\hline Barbus callensis & & & \\
S1 & 35 & $44.23 \pm 17.11$ & $13.46 \pm 2.64$ \\
S2 & 25 & $43.56 \pm 13.72$ & $13.41 \pm 2.17$ \\
S3 & 24 & $44.12 \pm 14.92$ & $13.77 \pm 2.01$ \\
\hline Barbus nasus & 26 & $50.84 \pm 18.94$ & $14.51 \pm 2.54$ \\
S1 & & & \\
Lepomis macrochirus & 11 & $82.72 \pm 22.72$ & $14.54 \pm 2.43$ \\
S2 & & & \\
\hline
\end{tabular}

SD: standard deviation, S1: station 1, S2: station 2, S3: station 3.

TABLE 4: Contents of trace metals dosed in the muscles of studied fish species (mg/kg of wet weight).

\begin{tabular}{lcccccc}
\hline \multirow{2}{*}{ Species } & \multicolumn{2}{c}{$\mathrm{Cd}$} & \multicolumn{2}{c}{$\mathrm{Pb}$} & $\mathrm{Hg}$ & \\
& $\bar{X} \pm \mathrm{SD}$ & $\mathrm{m}-\mathrm{M}$ & $\bar{X} \pm \mathrm{SD}$ & $\mathrm{m}-\mathrm{M}$ & $\bar{X} \pm \mathrm{SD}$ & $\mathrm{m}-\mathrm{M}$ \\
\hline Lepomis macrochirus & $0.00175 \pm 0.0005$ & $0.001-0.002$ & $0.1085 \pm 0.0691$ & $0.033-0.200$ & $0.1083 \pm 0.0549$ & $0.062-0.187$ \\
Barbus callensis & $0.0028 \pm 0.001$ & $0.001-0.006$ & $0.0622 \pm 0.0182$ & $0.016-0.158$ & $0.0549 \pm 00237$ & $0.009-0.161$ \\
Barbus nasus & $0.0045 \pm 0.0006$ & $0.004-0.005$ & $0.101 \pm 0.0252$ & $0.065-0.119$ & $0.0985 \pm 0.0393$ & $0.067-0.154$ \\
\hline
\end{tabular}

$\mathrm{X}$ : mean, SD: standard deviation, $\mathrm{m}$ : minimum, M: maximum

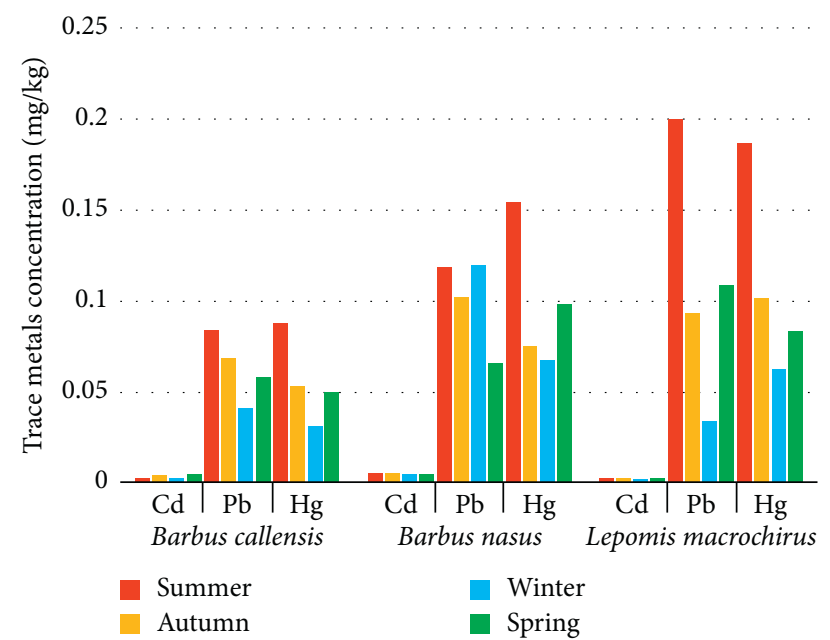

Figure 3: Seasonal variation in mean trace metals concentrations in muscles of the three fish species (mg/kg of wet weight). 
TABLE 5: Comparisons of recorded trace metal levels in the muscles of the fish species during the present study with literature reported from different areas (mg/kg of wet weight).

\begin{tabular}{|c|c|c|c|c|c|}
\hline Fish species & Region & $\mathrm{Cd}$ & $\mathrm{Pb}$ & $\mathrm{Hg}$ & References \\
\hline Barbus meridionalis & $\begin{array}{l}\text { Ripoll River in } \\
\text { Catalonia (Spain) }\end{array}$ & 0.0004 & 0.0092 & 0.2242 & [15] \\
\hline Barbus barbus and Anguilla anguilla & $\begin{array}{c}\text { Sûre River } \\
\text { (Luxembourg) }\end{array}$ & $0.028,0.021$, resp. & $0.034,0.034$, resp. & $\begin{array}{l}\text { 0.096, } 0.317 \\
\text { resp. }\end{array}$ & {$[19]$} \\
\hline $\begin{array}{l}\text { Hypophthalmichthys molitrix, Carassius } \\
\text { auratus, Coreius heterodon, and Silurus } \\
\text { asotus }\end{array}$ & Yangtze River (China) & $\begin{array}{c}0.062,0.132 \\
0.085,0.115, \text { resp. }\end{array}$ & $\begin{array}{c}0.529,0.811,0.53 \\
0.55, \text { resp. }\end{array}$ & $\begin{array}{l}0.006,0.0079 \\
0.005,0.0304 \\
\quad \text { resp. }\end{array}$ & {$[21]$} \\
\hline Lepomis gibbosus & Šalek Lake (Slovenia) & $<0.01$ & 0.02 & 0.08 & {$[17]$} \\
\hline $\begin{array}{l}\text { Cyprinus carpio, Carassius auratus } \\
\text { gibelio, and Scardinius erythrophthalmus }\end{array}$ & $\begin{array}{l}\text { Neretva river (Bosna } \\
\text { and Herzegovina) }\end{array}$ & $\begin{array}{l}0.013,0.045 \\
0.023, \text { resp. }\end{array}$ & $\begin{array}{l}0.073,0.055,0.066 \\
\text { resp. }\end{array}$ & $\begin{array}{l}0.083,0.050 \\
0.080, \text { resp. }\end{array}$ & {$[23]$} \\
\hline Pseudoplatystoma corruscans & $\begin{array}{c}\text { Paraopeba River } \\
\text { (Brazil) }\end{array}$ & $0.07-0.19$ & $0.94-3.31$ & $0.35-0.41$ & {$[22]$} \\
\hline $\begin{array}{l}\text { Luciobarbus graellsii, and Lepomis } \\
\text { gibbosus }\end{array}$ & $\begin{array}{l}\text { Station } 1 \text { of Llobregat } \\
\text { River (Spain) }\end{array}$ & $0.007,0.009$, resp. & $0.095,0.078$, resp. & - & {$[16]$} \\
\hline Barbus callensis and Liza ramada & $\begin{array}{c}\text { Loukkos river estuary } \\
\text { (Morocco) }\end{array}$ & $0.02,0.02$, resp. & $0.06,0.13$, resp. & - & {$[18]$} \\
\hline Perca flavescens & $\begin{array}{l}\text { A range of lakes } \\
\text { (Canada) }\end{array}$ & $0.338-2.598$ & - & - & {$[20]$} \\
\hline Micropterus salmoides & Sipsey River (USA) & - & - & 0.87 & {$[24]$} \\
\hline $\begin{array}{l}\text { Anguilla anguilla, Leuciscus cephalus } \\
\text { cabeda, and Chondrostoma toxostoma }\end{array}$ & Cecina River (Italy) & - & - & $\begin{array}{l}0.82,0.558,0.65 \\
\text { resp. }\end{array}$ & {$[25]$} \\
\hline Gambusia holbrooki & $\begin{array}{l}\text { Fouarat Lake and } \\
\text { Sebou estuary } \\
\text { (Morocco) }\end{array}$ & - & $0.0002-0.1967$ & 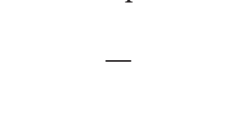 & {$[26]$} \\
\hline Anguilla anguilla & $\begin{array}{l}\text { Sebou estuary } \\
\text { (Morocco) }\end{array}$ & - & 0.00036 & - & {$[27]$} \\
\hline
\end{tabular}

TABLE 6: Matrix of correlation between the different trace metals in different fish species.

\begin{tabular}{lccc}
\hline & $\mathrm{Cd}$ & $\mathrm{Pb}$ & $\mathrm{Hg}$ \\
\hline $\mathrm{Cd}$ & 1 & & \\
$\mathrm{~Pb}$ & -0.02978876 & 1 & \\
$\mathrm{Hg}$ & -0.05063245 & 0.99978242 & 1 \\
\hline
\end{tabular}

TABLE 7: The order of the bioaccumulation of trace metals in the muscles of the studied fish species.

\begin{tabular}{|c|c|}
\hline $\begin{array}{l}\text { Trace } \\
\text { metals }\end{array}$ & Order of metal bioaccumulation \\
\hline $\mathrm{Cd}$ & $\begin{array}{c}\text { Barbus nasus }>\text { Barbus callensis }>\text { Lepomis } \\
\text { macrochirus }\end{array}$ \\
\hline $\mathrm{Pb}$ & $\begin{array}{c}\text { Lepomis macrochirus }>\text { Barbus nasus }>\text { Barbus } \\
\text { callensis }\end{array}$ \\
\hline $\mathrm{Hg}$ & $\begin{array}{c}\text { Lepomis macrochirus }>\text { Barbus nasus }>\text { Barbus } \\
\text { callensis }\end{array}$ \\
\hline
\end{tabular}

Petkovšek et al. [17] compared to our results. On the other hand, some studies showed high contents of lead in the muscles of fish, such as those of Yi and Zhang. [21] and Arantes et al. [22] (Table 5).

Very high positive correlations were recorded between the bioaccumulation of lead and mercury at a level of signification $(P<0.05)$ for the fish in these stations, whose correlation coefficient is 0.9997 (Table 6).

The order of the bioaccumulation of lead in the muscles of the studied fish species is relatively high in Lepomis macrochirus (Table 7).
This signals also that lead concentration in the muscles of studied fish species is much less than the regulation limit of lead in the flesh of fish $(0.3 \mathrm{mg} / \mathrm{kg}$ of wet weight $)$ according to Commission Regulation (EC) No. 1881/2006 [28].

The results of mercury measured in the fish muscles show that the lowest value is $0.009 \mathrm{mg} / \mathrm{kg}$ of wet weight in Barbus callensis captured in station 2, and the highest value is $0.187 \mathrm{mg} / \mathrm{kg}$ of wet weight in Lepomis macrochirus captured in station 2 (Table 4).

Close values were found by Boscher et al. [19] in Barbus barbus from the Sûre River in Luxembourg, Petkovšek et al. [17] on Lepomis gibbosus from the Šalek Lakes in Slovenia, and Djedjibegovic et al. [23] in the muscles of different fish species from Neretva River in Bosna and Herzegovina. However, low concentrations of mercury were found in the muscles of different fish species from the Yangtze River in China [21]. On the contrary, high concentrations of mercury were found in the muscles of Barbus meridionalis from the Ripoll River in Spain [15], in the muscles of Micropterus salmoides from the Sipsey River in USA [24], and in the muscles of different fish species from the Cecina River in Italy [25]. In addition, high concentrations were found in the muscles of Pseudoplatystoma corruscans from the Paraopeba River in Brazil [22] (Table 5).

Mercury and lead are strongly correlated at a level of signification $(P<0.05)$ for the fish in these stations, whose correlation coefficient is 0.9997 (Table 6).

The order of the bioaccumulation of mercury in the muscles of the studied fish species is relatively high in Lepomis macrochirus (Table 7). 
No species exceeded the maximum concentrations $(0.5 \mathrm{mg} / \mathrm{kg}$ of wet weight) set by Commission Regulation (EC) No. 1881/2006 [28].

The muscles of Lepomis macrochirus contain high concentrations of mercury and lead, attaining a value of $0.187 \mathrm{mg} /$ $\mathrm{kg}$ of wet weight for mercury and $0.200 \mathrm{mg} / \mathrm{kg}$ of wet weight for lead. This can be attributed to the nature of the food of this fish species, as it is considered very voracious eater feeding on almost everything, thus having a strong accumulation of trace metals in its body $[12,29]$. The relatively high concentrations of lead and mercury in the muscles of Barbus Nasus and Barbus callensis captured in station 1 may be due to significant bioaccumulation, probably related to the high concentrations of lead and mercury in the station itself.

Comparison of the mean concentrations of trace metals detected in the muscles of the fish species studied shows that lead contents are the highest compared to those of mercury and cadmium (Table 8). From these results, we can establish the general order of bioaccumulation of the trace metals measured in the muscles of the different fish species which is as follows: $\mathrm{Pb}>\mathrm{Hg}>\mathrm{Cd}$. According to reported results [30-32], trace metals bioaccumulation is related to fish species, type of trace metals, length/age, and physical and chemical characteristics of water. Several studies have demonstrated that cadmium has a low tendency to accumulate in muscles, where the concentrations are usually very low $[10,33]$. Unlike cadmium, mercury preferentially accumulates in muscles due to their affinity for the sulfhydryl groups of proteins [15]. The analysis of the physicochemical parameters shows that the water of the Moulouya River has high dissolved organic matter values and an alkaline $\mathrm{pH}$ $[3,34]$, which may decrease the bioavailability of trace metals in water column [35], therefore inducing a decrease in the rate of absorption and accumulation of trace metals in fish muscles. Otherwise, the high levels of dissolved organic matter may also increase microbial activity which is responsible for the release of trace metals from sediment to the water column $[15,35]$. In addition, the high water temperatures of the Moulouya River recorded during the summer season [3] lead to an increase in fish metabolism that could also increase pollution effects on fish [15].

Tissue concentrations found in dry weight were converted to wet weight by multiplying by a factor of 0.2 (considering an average water content in fish tissues of 80\%) [36].

The space analysis of trace metals in the muscles of the studied fish species shows a positive correlation between the intensity of trace metals and some stations. Therefore, as illustrated in Table 9, it was noted well that station 1 contains fish more contaminated with trace metals than other stations, which can be attributed primarily to the urban discharges from the city of Zaio which are loaded in trace metals and secondly to the industrial discharges of the refinery of sugar. Several studies have shown that the sugar industries wastewaters are loaded with organic matter and have a negative impact on the physicochemical parameters of the water [37-39]. In addition, some other studies have shown that the effluents of sugar factories can contain relatively high levels of trace metals [39-41]. Concerning stations 2 and 3, we note that the values of the trace metals in the muscles of the studied
TABLE 8: Order of trace metals accumulated in the fish muscles.

\begin{tabular}{lc}
\hline Species & Order \\
\hline Lepomis macrochirus & $\mathrm{Pb}>\mathrm{Hg}>\mathrm{Cd}$ \\
Barbus callensis & $\mathrm{Pb}>\mathrm{Hg}>\mathrm{Cd}$ \\
Barbus nasus & $\mathrm{Pb}>\mathrm{Hg}>\mathrm{Cd}$ \\
\hline
\end{tabular}

TABLE 9: The order of enrichment of stations for each trace metals in the fish muscles.

\begin{tabular}{lc}
\hline Trace metals & Enrichment orders \\
\hline $\mathrm{Cd}$ & $\mathrm{S} 1>\mathrm{S} 3>\mathrm{S} 2$ \\
$\mathrm{~Pb}$ & $\mathrm{~S} 1>\mathrm{S} 2>\mathrm{S} 3$ \\
$\mathrm{Hg}$ & $\mathrm{S} 1>\mathrm{S} 2>\mathrm{S} 3$ \\
\hline
\end{tabular}

S1: station 1, S2: station 2, S3: station 3 .

fish species are less than those in station 1, because these two stations (2 and 3) do not receive domestic and industrial discharges, even though they are located below the confluence point of the Moulouya with Charaâ river for station 3 and Lakhmis river for station 2, but their low flows do not help them reach Moulouya River. The explanation that can be given in terms of sources of trace metals in these two stations (station 2 and station 3 ) is the leaching of agricultural land during rainy periods (mainly in winter) and maybe also the road traffic mainly for station 3 located near ancient bridge of Ras El Ma-Moulouya. It is also potentially related to high evaporation of river water, which caused an increase in the concentrations of trace metals in the water.

The seasonal variation of trace metals in the muscles of the studied fish species has slightly high concentrations during summer season (Figure 3), in view of the fact that the weak flow of Moulouya River during this season does not seem to dilute the industrial and domestic discharges of tributaries. However, the winter is the season when contents of trace metals are very low, so strong flow of currents leads to the dispersion of trace metals. Moreover, the very high temperatures in the summer could also lead to higher metabolic rates, which could induce an increase in fish food activity, and this in turn increases the concentration of metals in fish $[42,43]$. Thus, the concentration of trace metals in a fish is the product of a balance between the concentration of the metal in its environment and its rate of ingestion and excretion by fish $[44,45]$. This result is in agreement with the studies of Mazini [46], Orban et al. [47], Obasohan [44], and Kassegne et al. [43].

Although concentration of trace metals in the muscles of the studied species does not exceed the proposed limit values, it is correlated with other contaminants (pesticides, PCB) likely to increase toxic effects on fish-farming fauna [48]. Therefore, further studies are needed to identify all pollutants that may threaten the health of fish and fish consumers in this area and to determine the relationships between them.

\section{Conclusions}

According to the present results, we have noted that mercury and lead are both trace metals most concentrated in the muscles of the studied fish (it attained $0.187 \mathrm{mg} / \mathrm{kg}$ of wet 
weight for mercury and $0.200 \mathrm{mg} / \mathrm{kg}$ of wet weight for lead), while cadmium is the metal with the lowest concentration (does not exceed $0.006 \mathrm{mg} / \mathrm{kg}$ of wet weight). Station 1 (confluence of Moulouya River with Sebra River) includes fish most contaminated with trace metals, because of their exposure to the domestic discharges of the city Zaio and industrial discharges from the Sucrafor sugar factory in Zaio. Lepomis macrochirus is the species with the highest values of trace metals, while the season that records the highest concentrations of trace metals is the summer. All concentrations of three traces metals (lead, cadmium, and mercury) found in the muscles of the different studied fish species have values not exceeding the regulation limit of the European Community (EC), so the consumption of the fish in lower Moulouya of Morocco is not dangerous for human health.

\section{Data Availability}

The data used to support the findings of this study are available from the corresponding author upon request.

\section{Conflicts of Interest}

The authors declare that there are no conflicts of interest regarding the publication of this work.

\section{References}

[1] M. Makhoukh, M. Sbaa, and A. Berrahou, "Contribution a L'etude physico-chimique des eaux superficielles de L'oued moulouya," Larhyss Journal, vol. 9, no. 9, pp. 149-169, 2011.

[2] M. Melhaoui and J. P. Boudot, "Diagnostic de la biodivesité aquatique dans le bassin hydraulique de la Moulouya," projet UICN/ABHM Moulouya-Maroc Rapport d'éxpertise, UICN Med, p. 114, 2009, https://lemondedecathy.fr/image/2014/04/ diagnostic_de_la_biodiversite_aquatique_fr.pdf.

[3] A. Brahimi, A. Chafi, and M. Mouzouri, "Physico-chemical typology of the quality of waters of the oued moulouya river and its tributary oued sebra (lower moulouya Morocco north oriental)," Journal of Chemical and Pharmaceutical Reseaerch, vol. 6, no. 7, pp. 54-62, 2014.

[4] A. Fahssi, H. S. Ali Yahya, R. Touzani et al., "Evaluation spatiotemporelle de la contamination métallique des ressources hydriques superficielles de la basse Moulouya," Journal of Materials and Environmental Science, vol. 7, no. 7, pp. 2404-2423, 2016.

[5] A. Tovar-Sánchez, G. Basterretxea, M. Ben omar et al., "Nutrients, trace metals and B-vitamin composition of the Moulouya river: a major north african river discharging into the mediterranean sea," Estuarine, Coastal and Shelf Science, vol. 176, pp. 47-57, 2016.

[6] S. Arrach, "Etude hydrologique de l'embouchure de la Moulouya et proposition de schéma d'aménagement et de gestion," Rapport de projet FEM/Banque Mondiale, p. 91, GEF/World Bank, Washington, DC, USAGEF/World Bank, 2014.

[7] A. Arumugam, J. Li, P. Krishnamurthy et al., "Investigation of toxic elements in Carassius gibelio and Sinanodonta woodiana and its health risk to humans," . Environmental Science and Pollution Research, vol. 27, pp. 19955-19969, 2020.

[8] A. Arulkumar, S. Paramasivam, and R. Rajaram, "Toxic heavy metals in commercially important food fishes collected from
Palk Bay, Southeastern India," Marine Pollution Bulletin, vol. 119, no. 1, pp. 454-459, 2017.

[9] M. M. Storelli, R. Giacominelli-Stuffler, A. Storelli et al., "Accumulation of mercury, cadmium, lead and arsenic in swordfish and bluefin tuna from the Mediterranean Sea: a comparative study," Marine Pollution Bulletin, vol. 50, pp. 993-1018, 2005.

[10] R. Merciai, C. Rodríguez-Prieto, J. Torres, and M. Casadevall, "Bioaccumulation of mercury and other trace elements in bottom-dwelling omnivorous fishes: the case of Diplodus sargus (L.) (Osteichthyes: sparidae)," Marine Pollution Bulletin, vol. 136, pp. 10-21, 2018.

[11] I. Rahhou, A. Maamri, M. Melhaoui et al., "Bioaccumulation de quelques éléments métalliques $(\mathrm{Zn}, \mathrm{Cu} \mathrm{Pb}, \mathrm{Fe}, \mathrm{Cd})$ chez la civelle d'anguille (Anguilla anguilla) au niveau de l'estuaire de la Moulouya (Est du Maroc)," Mar Life, vol. 11, no. 1-2, pp. 33-38, 2001.

[12] A. Azeroual, Monographie des Poissons des eaux continentales du Maroc: systématique, distribution et écologie, Ph.D. thesis, Faculté des Sciences, Université Mohammed V-Agdal, Rabat, Morocco, p. 193, 2003, https:/www.researchgate.net/ publication/237081221_Monographie_des_Poissons_des_ eaux_continentales_du_Maroc_systematique_distribution_ et_ecologie.

[13] AOAC, AOAC Official Method 999.10 Lead, Cadmium, Zinc, Cooper, and Iron in Foods, Atomic Absorption Spectrophotomoetry after Micowave Digestion, pp. 17-19, AOAC, Rockville, MD, USA, 2002.

[14] ISO/IEC 17025, "General requirements for the competence of testing and calibration laboratories," 2017. https://www.iso. org/obp/ui/\#iso:std:iso-iec:17025:ed-3:v1:en.

[15] A. Maceda-Veiga, M. Monroy, and A. de Sostoa, "Metal bioaccumulation in the Mediterranean barbel (Barbus meridionalis) in a Mediterranean River receiving effluents from urban and industrial wastewater treatment plants," Ecotoxicology and Environmental Safety, vol. 76, no. 1, pp. 93-101, 2012.

[16] R. Merciai, H. Guasch, A. Kumar, S. Sabater, and E. GarcíaBerthou, "Trace metal concentration and fish size: variation among fish species in a Mediterranean river," Ecotoxicology and Environmental Safety, vol. 107, pp. 154-161, 2014.

[17] S. A. S. Petkovšek, Z. M. Grudnik, and B. Pokorny, "Heavy metals and arsenic concentrations in ten fish species from the Šalek lakes (Slovenia): assessment of potential human health risk due to fish consumption," Environmental Monitoring and Assessment, vol. 184, pp. 2647-2662, 2012.

[18] M. El Morhit, M. Fekhaoui, A. El Morhit et al., "Hydrochemical characteristics and metallic quality in fish in the loukkos river estuary of Morocco," Journal of Materials and Environmental Science, vol. 4, no. 6, pp. 893-904, 2013.

[19] A. Boscher, S. Gobert, C. Guignard et al., "Chemical contaminants in fish species from rivers in the North of Luxembourg: potential impact on the Eurasian otter (Lutra lutra)," Chemosphere, vol. 78, no. 7, pp. 785-792, 2010.

[20] J. W. Rajotte and P. Couture, "Effects of environmental metal contamination on the condition, swimming performance, and tissue metabolic capacities of wild yellow perch (Perca flavescens)," Canadian Journal of Fisheries and Aquatic Sciences, vol. 59, no. 8, pp. 1296-1304, 2002.

[21] Y. J. Yi and S. H. Zhang, "The relationships between fish heavy metal concentrations and fish size in the upper and middle reach of Yangtze river," Procedia Environmental Sciences, vol. 13, pp. 1699-1707, 2012. 
[22] F. P. Arantes, L. A. Savassi, H. B. Santos, M. V. T. Gomes, and N. Bazzoli, "Bioaccumulation of mercury, cadmium, zinc, chromium, and lead in muscle, liver, and spleen tissues of a large commercially valuable catfish species from Brazil," Anais da Academia Brasileira de Ciências, vol. 88, no. 1, pp. 137-147, 2016.

[23] J. Djedjibegovic, T. Larssen, A. Skrbo, A. Marjanović, and M. Sober, "Contents of cadmium, copper, mercury and lead in fish from the Neretva river (Bosnia and Herzegovina) determined by inductively coupled plasma mass spectrometry (ICP-MS)," Food Chemistry, vol. 131, no. 2, pp. 469-476, 2012.

[24] P. S. Dharampal and R. H. Findlay, "Mercury levels in largemouth bass (Micropterus salmoides) from regulated and unregulated rivers," Chemosphere, vol. 170, pp. 134-140, 2017.

[25] R. Scerbo, T. Ristori, B. Stefanini, S. De Ranieri, and C. Barghigiani, "Mercury assessment and evaluation of its impact on fish in the Cecina river basin (Tuscany, Italy)," Environmental Pollution, vol. 135, no. 1, pp. 179-186, 2005.

[26] B. El Bouhali, L. Bennasser, I. Nasri et al., "Contamination métallique de Gambusia holbrooki au niveau du lac Fouarat et de l'estuaire Sebou dans la région du Gharb (Maroc)," Afrique Science, vol. 4, no. 3, pp. 410-425, 2008.

[27] F. Wariaghli, A. Tigilliman, A. El abidi et al., "Evaluation of the degree of heavy metal contamination in the Sebou estuary and in Moulay Bousselham lagoon reserve (Morocco)," International Journal of Aquatic Science, vol. 4, no. 2, pp. 69-82, 2013.

[28] The Commission of the European Communities, Commission Regulation (EC) $N^{\circ} 1881 / 2006$ of 19 December 2006, Setting Maximum Levels for Certain Contaminants in Foodstuffs, Official Journal of the European Union, Brussels, Belgium, 2006.

[29] P. Ndaleni, R. Wasserman, B. Ellender, and O. Weyl, "Diet of bluegill Lepomis macrochirus in a South African reservoir during winter and summer," African Journal of Aquatic Science, vol. 43, no. 1, pp. 85-88, 2018.

[30] M. I. Castro-González and M. Méndez-Armenta, "Heavy metals: implications associated to fish consumption," Environmental Toxicology and Pharmacology, vol. 26, no. 3, pp. 263-271, 2008.

[31] M. M. Storelli, "Potential human health risks from metals (Hg, $\mathrm{Cd}$, and $\mathrm{Pb}$ ) and polychlorinated biphenyls (PCBs) via seafood consumption: estimation of target hazard quotients (THQs) and toxic equivalents (TEQs)," Food and Chemical Toxicology, vol. 46, no. 8, pp. 2782-2788, 2008.

[32] N. Nasyitah Sobihah, A. Ahmad Zaharin, M. Khairul Nizam, L. Ley Juen, and K. Kyoung-Woong, "Bioaccumulation of heavy metals in maricultured fish, Lates calcarifer (Barramudi), Lutjanus campechanus (red snapper) and Lutjanus griseus (grey snapper)," Chemosphere, vol. 197, pp. 318-324, 2018.

[33] C. Vieira, S. Morais, S. Ramos, C. Delerue-Matos, and M. B. P. P. Oliveira, "Mercury, cadmium, lead and arsenic levels in three pelagic fish species from the Atlantic Ocean: intra- and inter-specific variability and human health risks for consumption," Food and Chemical Toxicology, vol. 49, no. 4, pp. 923-932, 2011.

[34] A. F. Taybi, Y. Mabrouki, A. Berrahou et al., "Évolution spatiotemporelle des paramètres physico-chimiques de la Moulouya," J. Mater. Environ. Sci, vol. 7, pp. 272-284, 2016.

[35] R. T. Di Giulo and D. E. Hinton, The Toxicology of Fishes, p. 1096, CRC Press, Taylor \& Francis, Boca Raton, FL, USA, 2008.
[36] C. Shinn, F. Dauba, G. Grenouillet et al., "Temporal variation of heavy metal contamination in fish of the river lot in southern France," Ecotoxicology Environmental Safety, vol. 72, no. 7, pp. 1957-1965, 2009.

[37] K. M. Doke, E. M. Khan, J. Rapolu et al., "Physico-chemical analysis of sugar industry Effluent and its effect on Seed germination of vigna Angularis, vigna cylindrical and sorghum cernum," Annals of Environmental Science, vol. 5, pp. 7-11, 2011.

[38] P. K. Poddar and O. Sahu, "Quality and management of wastewater in sugar industry," Applied Water Science, vol. 7, no. 1, pp. 461-468, 2017.

[39] J. Fito, N. Tefera, H. Kloos, and S. W. H. Van Hulle, "Physicochemical properties of the sugar industry and ethanol distillery wastewater and their impact on the environment," Sugar Tech, vol. 21, no. 2, pp. 265-277, 2018.

[40] F. Abraham Samuel, V. Mohan, and L. Jeyanthi Rebecca, "Physicochemical and heavy metal analysis of sugar mill effluent," Journal of Chemical and Pharmaceutical Research, vol. 6, pp. 585-587, 2014.

[41] B. Suresh, G. Sudhakar, and T. Damodharam, "Determination of heavy metals in sugar industry effluent," International Journal Of Modern Engineering Research, vol. 5, pp. 23-26, 2015.

[42] K. Sunjog, S. Kolarević, M. Kračun-Kolarević et al., "Seasonal variation in metal concentration in various tissues of the European chub (Squalius cephalus L.)," Environmental Science and Pollution Research, vol. 26, no. 9, pp. 9232-9243, 2019.

[43] A. Kassegne, T. Berhanu, J. Okonkwo, and S. Leta, “Assessment of trace metals in water samples and tissues of african catfish (Clarias gariepinus) from the akaki river catchment and the aba samuel reservoir, central Ethiopia," African Journal of Aquatic Science, vol. 44, no. 4, pp. 389-399, 2019.

[44] E. E. Obasohan, "The use of heavy metals load as an indicator of the suitability of the water and fish of Ibiekuma Stream for domestic and consumption purposes," African Journal of Biotechnology, vol. 7, no. 23, pp. 4345-4348, 2008.

[45] D. G. Smith, "Sources of heavy metal input to the New Zealand aquatic environment," Journal of the Royal Society of New Zealand, vol. 15, no. 4, pp. 371-384, 1985.

[46] B. Mazini, Pollution de l'environnement marin et santé humaine: mesure, évaluation et Impact des contaminants chimiques et biologiques dans les produits de la pêche au niveau du littoral marocain, Ph.D. thesis, Faculté des Sciences et techniques, Université Abdelmalek Essaadi., Tangier, Morocco, p. 184, 2012, http://thesesenafrique.imist.ma/bitstream/handle/123456789/16 93/THESE_BAGHDADI\%20MAZINI.pdf?sequence=1.

[47] E. Orban, G. Di lena, T. Nevigato, I. Casini, A. Marzetti, and R. Caproni, "Seasonal changes in meat content, condition index and chemical composition of mussels (Mytilus galloprovincialis) cultured in two different Italian sites," Food Chemistry, vol. 77, no. 1, pp. 57-65, 2002.

[48] M. Bellés, M. L. Albina, D. J. Sánchez, J. Corbella, and J. L. Domingo, "Interactions in developmental toxicology: effects of concurrent exposure to lead, organic mercury, and arsenic in pregnant mice," Archives of Environmental Contamination and Toxicology, vol. 42, no. 1, pp. 93-98, 2002. 